BIOEDUSCIENCE

ISSN: 2614-1558

http://journal.uhamka.ac.id/index.php/bioeduscience

\title{
Environmental Topics in Biological Learning: Systematic Study of National Journal Article Indexed Sinta
}

\section{Sang Putu Kaler Surata1, Ni Wayan Ekayanti1 ${ }^{*}$, Anak Agung Inten Paraniti1}

${ }^{1}$ Universitas Mahasaraswati Denpasar, Jalan Kamboja No.11A, Denpasar, Indonesia 80233

*Corespondent Email: ekayanti@unmas.ac.id

\section{ARTICLE INFO}

\section{Article history}

Received: 22 Nov 2020

Accepted: 09 Aug 2021

Published: 31 Des 2021

\section{Keywords:}

Biology education and

environment;

Measurable results;

Systematic review;

Transformative learning;

\section{A B S T R A C T}

Background: Biology and the environment have close interactions in biodiversity, biosphere and ecosystems. The study was systematically conducted on research articles to identify environmental topics in biological education, outline the research characteristics of biological education, and synthesise research trends and gaps on environmental topics in biological education in Indonesia. Method: Cross-sectional study design is conducted through a survey of research articles published in national journals. Results: A meta-analysis of the structure and content of 41 articles in the indexed journal Sinta 1-3 found environmental pollution was the most discussed topic, followed by several other topics such as biodiversity, ecosystems and conservation. Conclusion: Most research uses experimental design and development research with structured instruments to obtain measurable learning outcomes. Therefore, it is necessary to diversify biological education research to focus more on meaningful learning transformation through integrating biological education in other fields, especially biocultural diversity.

\section{A B S T R A K}

Kata kunci:
Jurnal terindeks sinta;
Pembelajaran
transformative;
Pendidikan biologi dan
lingkungan;
Sistematis review;

Background: Biologi dan lingkungan memiliki interaksi yang sangat erat dalam bentuk biodiversitas, biosfir dan ekosistem. Telaah secara sistematis dilakukan terhadap artikel hasil penelitian dengan tujuan mengidentifikasi topik lingkungan dalam pendidikan biologi, menguraikan karakteristik penelitian pendidikan biologi dan mensintesis kecenderungan dan kesenjangan penelitian tentang topik lingkungan dalam pendidikan biologi di Indonesia. Metode: Desain cross-sectional study dilakukan melalui survei terhadap artikel penelitian yang dipublikasikan dalam jurnal nasional. Hasil: Hasil meta-analisis terhadap struktur dan isi 41 artikel dalam jurnal terindeks Sinta 1-3, menemukan pencemaran lingkungan merupakan topik yang paling banyak dibahas diikuti dengan beberapa topik lainnya seperti keanekaragaman hayati, ekosistem dan konservasi. Kesimpulan: Sebagian besar penelitian menggunakan desain eksperimen dan riset pengembangan dengan instrumen yang terstruktur untuk mendapatkan hasil belajar yang terukur. Karena itu, diperlukan diversifikasi penelitian pendidikan biologi untuk lebih fokus pada transformasi pembelajaran bermakna melalui integrasi pendidikan biologi bidang lain terutama keanekaragaman biokultur. (C) 2021 by authors. Lisensi Bioeduscience, UHAMKA, Jakarta. This article is open access distributed under the terms and conditions of the Creative Commons Attribution (CC-BY) license.

\section{Introduction}

Biodiversity, biosphere and ecosystems are biologyrelated areas to the environment (Penick, 1995). Therefore, various topics and environmental issues are discussed in the curriculum of primary, secondary and higher education in various countries, including Indonesia. The main goal is to prepare students to individually and collaborate able to take positive actions in the environment, in addition to information transfer, improving knowledge, values and attitudes (N. Ardoin et al., 2018; N. M. Ardoin et al., 2020)

To achieve these goals, various learning strategies and models are used, such as integration with mathematics to achieve quantitative abilities (Goldstein \& Flynn, 2011), the art of drama to uncover social-science aspects of biology (Kinchin, 2011), poetry and drawing in the exploration of the impacts of climate change (Gebbels et al., 2011); various aspects of sustainable life education (Slingsby \& Barker, 2003), the complexity of climate change (Olander \& 
Olander, 2016), to explore the views of prospective teacher students about the relevance of science practising education in society (Mustanen \& Uitto, 2020).

Without exception in Indonesia, various environmental topics are discussed in the biological education curriculum, such as environmental pollution (Azizah \& Khuzaemah, E., Lesmanawati, 2017; Gloria et al., 2015; Jaelani et al., 2016; Maryuningsih \& Maemunah, 2013; Ratnasari et al., 2015), biodiversity (Ma'rifah \& Suryadarma, 2015), environmental biotechnology (Mardikaningtyas, D. A., Ibrohim \& Suarsini, 2016; Sa'diyah et al., 2016), ecosystem (Hartini et al., 2018; Ulva et al., 2017), conservation (Mansyur et al., 2016); IPA and environment (Ichsan et al., 2018).

However, there have not been many literature reviews on environmental topics in biological education, especially in Indonesia. Whereas systematic literature review has an important role, especially to overcome duplication or proliferation in research mapping specific areas of research while identifying strengths, weaknesses, and gaps in the study of specific fields(N. Ardoin et al., 2018); reduce errors in field research through identification, critical assessment, and appropriate research cystinosis (Petticrew \& Roberts, 2006). For this reason, the publication of a literature review related to environmental topics in biological education is needed. Thus, this study aims to (1) identify environmental topics in biology education (learning) in Indonesia; (2) outline the research characteristics of biological education, especially from the design, instruments and research results; (3) synthesize data related to trends and research gaps on environmental topics in biological education.

\section{Methods}

Cross-sectional study design is conducted through a survey of research articles published in national journals, from 2012 to early 2020 through a systematic review of articles. The study method refers to systematic literature review in accordance with Preferred reporting items for systematic reviews and meta-analyses (prisms) combined with environmental scope and topics in biology education (N. Ardoin et al., 2018). According to (Petticrew \& Roberts, 2006), SLR is a scientific method that seeks to reduce bias in conventional literature studies, by identifying, assessing and synthesizing the library studied to answer specific questions. Systematic study can help in making room for the implementation of research results by reflecting, considering, and respecting various methods and epistemology of research (Toomey et al., 2017).

After the data is tabulated in Microsoft Excel format, then the identification and analysis is carried out quantitatively and qualitatively. Quantitative analysis is done in the form of tabulation, analysis in the form of percentages, mean and standard deviation. Qualitative analysis is conducted coding, categorization and classification of the theme of research results. Furthermore, a synthesis of trends and evaluations about biological education research gaps related to environmental topics: validation and reliability mechanisms are carried out. Each author performs synthesis and evaluation independently. If there is a gap, then a consensus has reached an agreement.

\section{Results}

From the search of articles with environmental topics in biology learning that have been indexed, the articles examined are sourced from the journal Biological Education that has been indexed by DOAJ and Garuda Portal more than articles from biology journals. More than half of all journals examined contained Sinta-2, followed by Sinta- 3 and Sinta- 1 .

\section{Library Article Description}

Of the 136 articles that correspond to the topic of biology and environment in the Garuda portal, a total of 56 articles refer to the topic of biological and environmental education. In contrast, other articles are related to pure biology or published in proceedings. On the DOAJ portal, 78 articles were found based on biological and environmental education keywords. Once the article is repetitive (the same article is contained in both portals), the whole paper is inaccessible, and the topic covering pure biology is excluded from the sample. There are 41 articles eligible for further analysis.

Table 1 shows that about one-third (33\%) of library articles are published in the Journal of Education: Theory, Research, and Development, Scientiae Educatia: Journal of Science Education (25\%), Journal of Educational Innovation IPA (10\%), the rest, are published in nine other national journals with a percentage of 3-5\% each. About threequarters $(73 \%)$ of articles are contained in journals with the Sinta- 2 index, the rest in indexed journals Sinta-3 (22\%) and Sinta-1 (5\%).

Table 1. Journal name, SINTA index and number of articles from each journal

\begin{tabular}{|c|c|c|c|}
\hline Journal & SINTA & Sum & $(\%)$ \\
\hline $\begin{array}{l}\text { Journal of Education: Theory, } \\
\text { Research, and Development }\end{array}$ & Sinta 2 & 13 & 33 \\
\hline $\begin{array}{l}\text { Scientiae Educatia: Journal of } \\
\text { Science Education }\end{array}$ & Sinta 3 & 10 & 25 \\
\hline $\begin{array}{l}\text { Journal of Educational } \\
\text { Innovation IPA }\end{array}$ & Sinta 2 & 4 & 10 \\
\hline $\begin{array}{l}\text { Indonesian IPA Education } \\
\text { Journal }\end{array}$ & Sinta 1 & 2 & 5 \\
\hline $\begin{array}{l}\text { Biosphere: Journal of Biology and } \\
\text { Biological Education }\end{array}$ & Sinta 2 & 2 & 5 \\
\hline Journal of Bioedukatika & Sinta 2 & 2 & 5 \\
\hline Edusains & Sinta 2 & 2 & 5 \\
\hline Indonesian Journal of Education & Sinta 2 & 1 & \\
\hline JIPVA (Journal of VeteranS IPA & Sinta 3 & 1 & 3 \\
\hline
\end{tabular}




\section{Education)}

Education Science Sheet

Journal of Mathematics

Education and IPA

Indonesian Journal of Biological Education

\section{Library Article Environment Topics}

Figure 1 shows the number of articles on biological and environmental learning topics in the last ten years. The number of articles on the topic increased from 2012 to 2016, with the most published articles in 2016. Nevertheless, since 2017, the number of biology education articles on environmental topics will likely decrease until 2020. More than three-quarters (83\%) of the articles were published between 2014-2017

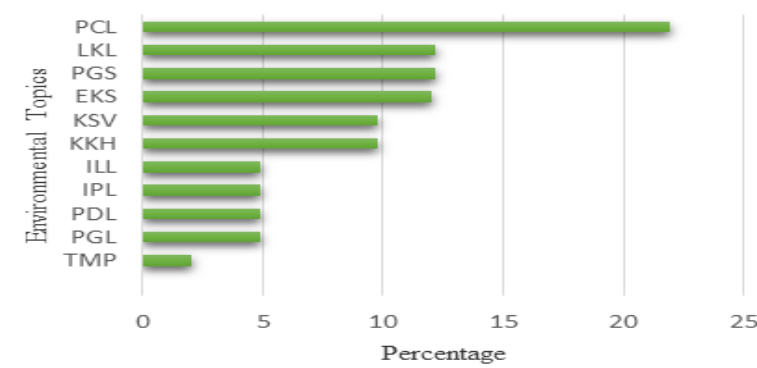

Figure 1. Tendency to publish articles with environmental topics in biological education in national journals 2012-2020

The analysis results get 12 environmental topics with environmental pollution as the most discussed topics in the article. This is because environmental pollution is a topic that is very close to life and contextually can be seen by students. Topics are further followed by the local environment, waste management, including waste, conservation, ecosystems, biodiversity, environmental science, IPA and environment, environmental education, environmental knowledge and tempeh making through mutual understanding (Figure 3).

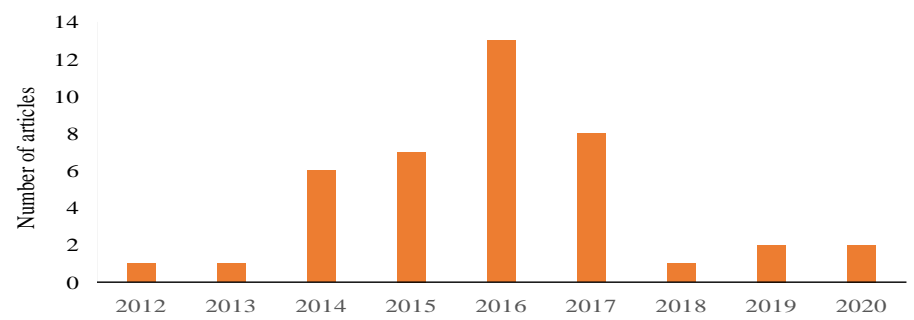

Year of publication

Figure 2. Environmental topics in biology education: environmental pollution (PCL), waste management (PGS), local environment (LKL), conservation (KSV), ecosystems (EKS), biodiversity (KKH), environmental science (ILL), IPL (IPA and environmental management), home area (KRP), environmental education (PDL), environmental knowledge (PGL), Tempe makings (TMP).
The local environmental category covers several issues such as applying the concept of Spermatophyta plants in the local arts Sintren, sustainable food house areas, Bejoe coastal environments, environmental education ecotourism area in Balikpapan. Conservation covers the topics of sustainable development, environmental management, environmental change and conservation efforts. At the same time, the category of ecosystem topics includes the topic of plant ecology and the interaction of living things and the environment.

\section{Desain Penelitian Artikel Pustaka}

Table 2 shows nearly half of the studies (19 articles; 46\%) using experimental methods (quasi-experiment and pre-experiment), 10 (24\%) with research and development design, or research and design (R\&D), the rest of class action research, a combination of $R \& D$ and experimentation, surveys and descriptive research with a percentage of 3-10 per cent each.

For quasi-experiment research, most use pre-post test control group design with various models and approaches to learning to experimental groups, such as the implementation of community technology science, local science and wisdom, science, environment, technology and community, blended project-based learning, guided inquiry learning, problem-based learning, conservation-based scientific approach, and application of snake-storytelling media. Pre-experiment research includes learning to instil environmentally caring character, using environmental biotechnology handouts as a source of learning, and implementing guided inquiries. $R \& D$ design includes the development of environmental management learning, environmental pollution learning, inquiry-based biology learning, and learning media, such as ecotourism guides, modules, booklets, environmental education textbooks, biodiversity textbooks, and learning devices (e.g. RPP, LKS and handouts).

Table 2. Frequency of research design in the article Design $\quad$ Information

\section{(\%)}

\begin{tabular}{lcl} 
Experiment & $\begin{array}{c}19 \\
(46)\end{array}$ & $\begin{array}{l}\text { Quasi-experiment: pre-post test control } \\
\text { group design (15) AND quasi- } \\
\text { experiment: post-test control group (2). } \\
\text { Pre-experiment: one group pre-post test } \\
\text { only (3). }\end{array}$ \\
R \&D & 10 & Borg \& Ball (5), ADDIE (3), N/A (2) \\
& $(24)$ & \\
PTK & 4 & PTK-lesson study (1); PTK (2) \\
$R \& D+$ Ekspe- & 4 & $\begin{array}{l}\text { Borg \& Ball (2); N/A (2); Pre- } \\
\text { experiment: one group pre-post test ony } \\
\text { rimen }\end{array}$ \\
& $\begin{array}{l}(10) ; \text { quasi experiment: pre-post test } \\
\text { control group (1), post test control }\end{array}$ \\
\hline
\end{tabular}




$$
\text { group (1) }
$$

$\begin{array}{lll}\text { Survey } & 3(7) & \text { Field survey (1); Survey documents (1) } \\ \begin{array}{lll}\text { Qualitative } \\ \text { descriptive }\end{array} & 1(3) & \text { N/A }\end{array}$

Description: N/A (not/available), no information about the development research model used, or the design of the research on descriptive research

\section{Instruments and Analysis of Library Article Data}

Figure 3 shows that more than a third of the study uses 2-3 research instruments, the rest using 1,4 and 5 instruments. Observation guidelines, questionnaires and tests are most widely used compared to rubrics and interviews. The observation guidelines consisted of activity observation sheets, critical thinking skills, environmental care attitudes, learning implementation, and learning products. Questionnaires are mainly used in R\&D research, such as expert validation questionnaires and participant response questionnaires to research products. The majority of tests are in multiple options to measure cognitive ability, especially learning outcomes. Rubrics in the form of participant assessment sheets on $R \& D$ research products, while questionnaires in the form of answer choices in the Likert Scale.

There is one questionnaire used to evaluate environmentally caring characters (Tivani \& Paidi, 2016). Most tests are in multiple-choice form, except for one study with an essay test (Juriah \& Zulfiani, 2019). Similarly, most tests measure cognitive ability, especially learning outcomes, except for some tests used to assess attitudes of environmental care (Mardiana et al., 2016), science literacy (Jaelani et al., 2016), effectiveness of teaching materials (Luzyawati \& Lissa, 2020). The type of instrument and data analysis used can be seen in Figure 3.
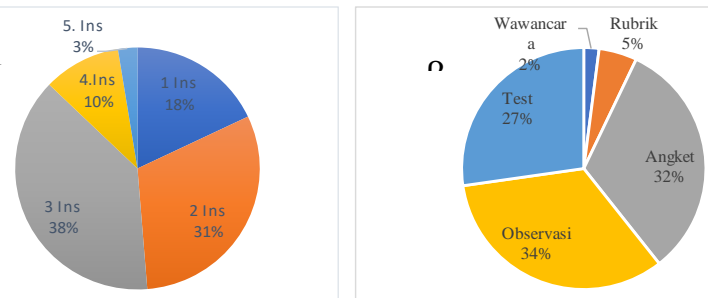

Figure 3. The number of instruments used in research (a) and the frequency of use of each instrument in the collection of research data $(b)$.

As for data analysis, more than half of the articles (51\%) use differential analysis in various forms, the rest a combination of inferential analysis, a combination of differential and inferential, and qualitative descriptive.

Table 3. Analysis of research data in the article

\begin{tabular}{|lccl|}
\hline Analysis & F & $\mathbf{( \% )}$ & Information \\
\hline 1. Differential & 21 & 51 & $\begin{array}{l}\text { Table, figure, percentage, } \\
\text { gain score }\end{array}$ \\
\hline
\end{tabular}

$\begin{array}{lccl}\text { 2. Inferential } & 6 & 15 & \begin{array}{l}\text { t-test, ANOVA dan } \\ \text { ANAKOVA }\end{array} \\ \begin{array}{l}\text { 3. Inferesnsial } \\ \text { Descriptive }\end{array} & 12 & 29 & \begin{array}{l}\text { percentage, gain score, t- } \\ \text { test, Wilcoxon test, Man } \\ \text { Withney test }\end{array} \\ \begin{array}{l}\text { 4. Qualitative } \\ \text { descriptive }\end{array} & 2 & 5 & \text { N/A }\end{array}$

Description: N/A (not available): a detailed description of qualitative descriptive analysis is not found in the article.

\section{Results of library article research}

The results of the research in the article analyzed were grouped into four categories: (1) cognitive, including problem formulation, understanding of concepts, ability to remember and ecological intelligence, (2) skills, covering activities, science process skills, critical thinking skills, and scientific skills), (3) attitudes, including response to learning, response to products, research, environmental and motivational caring attitudes, (4) others, including experimental literacy, creativity, character (spiritual, honest, disciplined, responsible, tolerance, mutual courtesy and confidence), potential learning resources, and related to R\&D products (validity, effectiveness and readability). Figure 4 shows about a quarter of the total articles included in other categories, more than the research results in knowledge, attitudes and skills. In the picture, there are also quite a lot of articles with a combination of two (e.g. knowledge and skills), three (e.g. a combination of knowledge, skills and attitudes) or even four categories of research results (knowledge, skills, attitudes and other aspects).

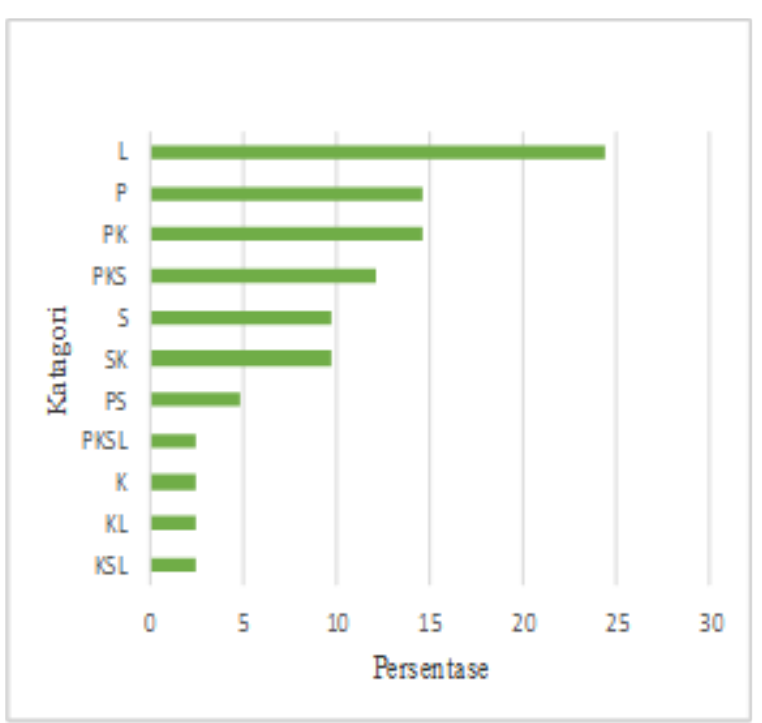

Figure 4. Categories of literature article research; other (L), knowledge (P), knowledge and skills (PK), knowledge, skills and attitudes (PKS), attitudes (S), attitudes and skills (SK), knowledge and attitudes (PS), knowledge, skills, attitudes and others, skills $(\mathrm{K})$, skills and others (KL), skills, attitudes and others (KSL). 


\section{Discussion}

A review of the library article found a reasonably broad environmental topic ranging from pollution issues to waste management, local environmental utilization, conservation, biodiversity, and biotechnology making tempeh. The two most widely used research designs in the study were quasiexperimental design (46\%) and R\&D (24\%), while related to instruments almost all (96\%) of the study collected data using structured instruments, such as rubrics, observation sheets, tests and questionnaires; The use of experimental design and $R \& D$ with structured instruments reflects the researcher's desire to produce a measurable external (N. Ardoin et al., 2018).

The results of the exploration also found various library articles with exciting structures and content, such as a combination of R\&D design and experiments (Ma'rifah \& Suryadarma, 2015; Maryuningsih, 2012; Tivani \& Paidi, 2016), qualitative descriptive design with PjBL model and sustainable food house coral module, the potential of tourist areas as learning resources (Ngabekti, 2014), science, environmental, technological and community learning approaches, video media-based PBL (Juriah \& Zulfiani, 2019), Lesson Study-Based Inquiry Model (Istiana \& Awaludin, 2018), analysis of IPA and environmental learning media needs (Ichsan et al., 2018). Furthermore, it was also found that some studies used test instruments not to measure cognitive abilities, but to assess environmental care attitudes (Mardiana et al., 2016), science literacy (Mansyur et al., 2016), the effectiveness of teaching materials (Luzyawati \& Lissa, 2020), as well as questionnaires to evaluate environmental caring characters (Tivani \& Paidi, 2016), not for expert validation and student response to R\&D products. Similarly, it was found that one study used the essay test as an alternative to the multiple choice test that became the instrument of most research in the literature article (Juriah \& Zulfiani, 2019).

The various research results that have been presented in this review show the flexibility of environmental topics in biological learning, and positive results about the learning that has been implemented. Although some studies have used interesting designs, approaches and instruments, further research is suggested using other research designs such as ethnography, case studies and participatory research. The development of instruments in subsequent research also needs to be considered, for example questionnaires with drawings, problem solving diagrams. The integration of biological learning with other fields of study also needs to be considered. Previous research has shown that the integration between active learning and quantitative skills by slightly modifying the practicum curriculum effectively enhances understanding of the importance of statistical concepts in biological education (Goldstein \& Flynn, 2011). (Kinchin, 2011) proves the use of concept maps can encourage teachers to become facilitators of meaningful learning by providing opportunities for students to construct their learning outcomes.

On the other hand, the research results on the use of images to identify the causes of air pollution revive science learning and is a very appropriate mechanism in allowing students to communicate their views on environmental issues to other members of society (Gebbels et al., 2011). No less exciting research with a grounded theory approach by (Mustanen \& Uitto, 2020) found student assessment of the gap between the curriculum of biological education and the practice of everyday science in society and nature. For a rich Indonesian context with a wide range of biocultural diversity, local environmental-oriented action studies need to be considered to recognize and strengthen the interaction between biology and socio-cultural systems of society (Toomey et al., 2017). For example, the diversity of bio-cultures in Subak culture is related to Hindu religious ritual activities in Bali, which link biodiversity, culture and the Balinese language. From this bio-culture can be found the relationship between the type of animal and the name of the animal (in Balinese) used in religious ritual activities, for example, is Ayam (Gallus gallus domesticus), whose fur is colourful, in Balinese called ready brumbun (fur or skin with white, red, yellow and black elements) used in Hindu religious ritual activities for Caru Eka Sata ceremonies; Caru Manca Sata, a driver.

The systematic review is done by assessing only library articles in two databases so that it does not include all articles that have been published. In addition, the articles examined only meet the criteria following the established study methods. Although the research team has tried objectively in terms and mechanisms of review, subjectivity is inevitable, as in deciding the categories of research results. Another limitation is that the study is done only on abstract or complete paper (full paper) articles that can be accessed online. Thus, it is possible to ignore articles worth further investigation but cannot be accessed online. The study was also limited to articles in national journals with indexes Sinta-1, 2 and 3, excluding articles with good research quality but published in journals outside the index. Sinta index criteria 1-3 are used to standardize the study to focus on articles published in journals with a peerreview process rated very good until good enough. The study is also limited to a relatively short duration of time. That way, this study does not include articles that meet the criteria but are published before or after that period. Article searches are done through the keywords "biological education" and "environment" so it is possible to ignore articles that do not explicitly use both keywords, but according to experts and other researchers, it should fall within the topic's scope. Despite all these limitations, the study is expected to contribute to broader discussions, 
encourage more process-oriented biological education research to evaluate the effects of learning on more environmentally friendly behaviour, and provide support in the integration of environmental education and biological education to produce a compatible curriculum for both fields of science.

\section{Conclusion}

This systematic study seeks to elaborate and critically analyze library articles related to environmental topics in biological education for primary, secondary and higher education levels. The topic studied in this research is the topic of biology and environmental learning in articles that have been published on the DoAJ and Garuda portals that have been indexed SINTA 1-3. The two most widely used research designs in this study are quasi-experimental design (46\%) and R\&D (24\%), then 96\% of studies examined using structured instruments, such as rubrics, observation sheets, tests, and questionnaires. The results showed the flexibility of environmental topics in biological learning and positive results about learning that its researchers had implemented. The characteristics of biological education research that has been studied in this study have a positive externality to knowledge, skills, attitudes, and produce various learning media products. The trends and gaps in research on environmental topics in biological education in Indonesia studied in this study reveal the approaches, designs, instruments and results of research that has been done so far and research that still needs to be explored in the future. In addition to focusing on measurable outcomes, biological education research is needed with different approaches, such as the ability to describe environmental issues, problems and challenges, and the experience to collaborate. The integration of bioculture diversity in biological education needs to be prioritized to provide students with meaningful experiences about the close interaction between biodiversity and cultural diversity (including the language) of the archipelago.

\section{Declaration statement}

The authors reported no potential conflict of interest.

\section{References}

Ardoin, N., M., A., W.B., Roth, N. W., \& Holthuis, N. (2018). Environmental education and K-12 student outcomes: A review and analysis of research. The Journal Environmental Education, 49 , https://doi.org/10.1080/00958964.2017.1366155

$1-17$

Ardoin, N. M., Bowers, A. W., \& Gaillard, E. (2020). Environmental education outcomes for conservation: A systematic review. Biological Conservation. 241, 108-224. https://doi.org/10.1016/j.biocon.2019.108224

Azizah, S., \& Khuzaemah, E., Lesmanawati, I. R. (2017) Penggunaan media internet eXe-Learning berbasis masalah pada materi perubahan lingkungan untuk meningkatkan hasil belajar siswa. Scientiae Educatia: Jurnal Pendidikan Sains, $6(2)$

https://syekhnurjati.ac.id/jurnal/index.php/sceducatia/art icle/view/1957

Gebbels, S., Hunter, J., Nunoo, F. K. E., Tagoe, E., \& Evans, S. M. (2011). Schoolchildren's use of poetry and paintings in conveying environmental messages. Journal of Biological Education, 46(2), 93-102. https://doi.org/10.1080/00219266.2011.583667

Gloria, R. Y., Azmi, N., \& Komariah, S. (2015). Penerapan pendekatan SETS (Science, Environment, Technology, Society) dalam pembelajaran biologi berbasis Imtaq untuk meningkatkan hasil belajar siswa pada konsep pencemaran lingkungan di SMA Negeri 8 Kota Cirebon. Scientiae Educatia: Jurnal Pendidikan Sains, 4(1), 73-82.

Goldstein, J., \& Flynn, F. B. (2011). Integrating active learning \& quantitative skills into undergraduate introductory biology curricula. The American Biology Teacher, 73, 454-461. https://doi.org/10.1525/abt.2011.73.8.6

Hartini, R. F., Ibrohim, I., \& Qohar, A. (2018). Pemahaman konsep dan keterampilan proses sains melalui inkuiri terbimbing berbasis lingkungan pada materi ekosistem. Jurnal Pendidikan: Teori, Penelitian, Dan Pengembangan, 3(9), 1168-1173.

Ichsan, I. Z., Dewi, A. K., Hermawati, F. M., \& Iriani, E. (2018). Pembelajaran IPA dan lingkungan: Analisis kebutuhan media pembelajaran pada SD, SMP, SMA di Tambun Selatan, Bekasi. Jurnal Pendidikan IPA Veteran (JIPVA), 2(2). https://doi.org/10.31331/jipva.v2i2.682

Istiana, R., \& Awaludin, M. T. (2018). Peningkatan kemampuan memecahkan permasalahan lingkungan pada mahasiswa pendidikan biologi dalam materi pengetahuan lingkungan melalui model inquiri berbasis lesson study. Biosfer: Jurnal Pendidikan Biologi (Biosferjpb), 11(1). https://doi.org/10.21009/biosferjpb.11-1.6

Jaelani, E., Wahidin, W., \& Roviati, E. (2016). Penerapan media ular tangga bercerita untuk meningkatkan keterampilan berpikir kritis siswa kelas vii pada konsep pencemaran lingkungan di mts al-muatawally kuningan. Scientiae Educatia: Jurnal Pendidikan Sains, 5(1). https://syekhnurjati.ac.id/Jurnal/Index.Php/Sceducatia/Ar ticle/View/962

Juriah, J., \& Zulfiani, Z. (2019). Penerapan model problem based learning berbantu media video untuk meningkatkan hasil belajar peserta didik pada konsep perubahan lingkungan dan upaya pelestarian. Edusains, 11(1). https://doi.org/10.15408/Es.V11i1.6394

Kinchin, I. A. (2011). Visualising knowledge structures in biology: discipline, curriculum and student understanding. Journal of Biological Education, 45, 183-189. https://doi.org/10.1080/00219266.2011.598178

Luzyawati, L., \& Lissa, L. (2020). Pengembangan buku ajar biodiversitas berbasis kajian etnobiologi suku dayak losarang. Jurnal Pendidikan Matematika Dan IPA, 11(1). http://dx.doi.org/10.26418/jpmipa.v11i1.37598

Ma'rifah, D. R., \& Suryadarma, I. G. P. (2015). Penyusunan panduan edutourism hutan wisata tlogo nirmolo guna memunculkan karakter peserta didik kelas X. Jurnal Inovasi Pendidikan IPA, 1(2). https://doi.org/10.21831/jipi.v1i2.7497

Mansyur, Y. A., Kartimi, K., \& Roviati, E. (2016). Penerapan pendekatan saintifik berbasis konservasi pada materi 
keanekaragaman makhluk hidup untuk meningkatkan hasil belajar siswa di SMPN 1 Gempol. Scientiae Educatia: Jurnal Pendidikan Sains, 5(1), 61-70.

Mardiana, M., Al Muhdhar, M. H. I., \& Sueb, S. (2016). Pengaruh modul program KRPI berbantuan Pembelajaran Berbasis Masalah (PBM) terhadap hasil belajar kognitif dan sikap peduli lingkungan siswa kelas VII SMPN 18 Malang. ,1 (1). Jurnal Pendidikan: Teori, Penelitian, Dan Pengembanga, 1(1).

Mardikaningtyas, D. A., Ibrohim, I., \& Suarsini, E. (2016). Pengembangan pembelajaran pencemaran lingkungan berbasis penelitian fitoremediasi untuk menunjang keterampilan ilmiah, sikap peduli lingkungan dan motivasi mahasiswa pada matakuliah dasar-dasar ilmu lingkungan. Jurnal Pendidikan: Teori, Penelitian, Dan Pengembangan, 1(3), 499-506.

Maryuningsih, Y. (2012). Pembelajaran pendidikan lingkungan hidup dengan Problem Base Learning (PBL) dapat menumbuhkan kemampuan kerja ilmiah pada siswa sekolah adiwiyata. Scientiae Educatia: Jurnal Pendidikan Sains, 1(1), 37-48.

Maryuningsih, Y., \& Maemunah, M. S. (2013). Penerapan model Sains Teknologi Masyarakat (STM) pada pokok bahasan pencemaran lingkungan untuk meningkatkan kreativitas siswa kelas x di SMAN 2 cirebon. Scientiae Educatia: Jurnal Pendidikan Sains, 2(2), 149-162.

Mustanen, J., \& Uitto, A. (2020). Make biology relevant again! preservice teachers' views on the relevance of biology education. Journal of Biological Education, 54(2), 202-212. https://doi.org/10.1080/00219266.2020.1739423

Ngabekti, S. (2014). Kawasan Wisata Pendidikan Lingkungan Hidup (KWPLH) Balikpapan sebagai sumber belajar konservasi. Jurnal Pendidikan IPA Indonesia, 3(2). https://doi.org/10.15294/jpii.v3i2.3109

Olander, M. H., \& Olander, C. (2016). Understandings of climate change articulated by swedish secondary school students. Journal of Biological Education, 51(4), 349-357. https://doi.org/10.1080/00219266.2016.1233130

Penick, J. E. (1995). New goals for biology education: Helping teachers make science accessible to more students.,. Bioscience, BioScience, 45, 52-57. https://doi.org/10.2307/1312444

Petticrew, M., \& Roberts, H. (2006). Systematic reviews in social sciene: A practical guide. 1st Ed. Victoria. Blackwell Publishing.

Ratnasari, R., Endang, E., \& Maknun, D. (2015). Penerapan model pembelajaran inkuiri terbimbing (guided inquiry) untuk meningkatkan sikap peduli terhadap lingkungan pada konsep pencemaran lingkungan di kelas VII SMP Negeri 3 Sumber. Scientiae Educatia, 4(2), 149-162.

Sa'diyah, W., Suarsini, E., \& Ibrohim, I. (2016). Pengembangan modul bioteknologi lingkungan berbasis penelitian matakuliah bioteknologi untuk mahasiswa S1 Universitas Negeri Malang. Jurnal Pendidikan: Teori, Penelitian, Dan Pengembangan, 1(9).

Slingsby, S., \& Barker, S. (2003). Making connections: Biology, environmental education and education for sustainable development. Journal of Biological Education, 38, 4-6. https://doi.org/10.1080/00219266.2003.9655888

Tivani, I., \& Paidi, P. (2016). Pengembangan LKS biologi berbasis masalah untuk meningkatkan kemampuan pemecahan masalah dan karakter peduli lingkungan. Jurnal Inovasi $\begin{array}{lll}\text { Pendidikan } & \text { Ipa, } & 2(2),\end{array}$ https://doi.org/10.21831/jipi.v2i1.8804

Toomey, A. H., Knight, A. T., \& Barlow, J. (2017). Navigating the space between research and implementation in conservation. , 10 (5), . A Journal of the Society for Conservation Biology, 10(5), 619-625.

Ulva, V., Ibrohim, I., \& Sutopo, S. (2017). Mengembangkan sikap ilmiah siswa smp melalui pembelajaran inkuiri terbimbing pada materi ekosistem. Jurnal Pendidikan: Teori, Penelitian, Dan Pengembangan, 2(5). 